\title{
THE PRODUCTIVE LONGEVITY OF PERENNIAL GRASSES SWARDS DEPENDING ON THE NPK FERTILIZER RATES
}

\author{
Berzins P., Rancane S., Svarta A. \\ LUA Research Institute of Agriculture \\ Zemkopibas instituts - 7, Skriveri, Skriveri distr., LV-5125, Latvia \\ Ph.: +(371) 26484676; fax: +(371) 65197954; e-mail: sarmite.rancane@inbox.lv
}

\begin{abstract}
The longevity and producing capacity of perennial grasses swards was studied on mineral soils at the LUA Research Institute of Agriculture in long-term experiment during 1974-2010. There were applied lime and mineral fertilizers with different NPK doses $\left(0-400 \mathrm{~kg} \mathrm{ha}^{-1}\right)$ protractedly many years. In such way there formed soils with various content of $P, K$, organic matter content and $\mathrm{pH}_{K C l}$ level as well. Research results showed that liming of soils and using of mineral fertilizer changed not only productivity of grass mixtures but also botanical composition. Mineral fertilizer $N_{200} P_{100} K_{300}$ provided the highest yield of dry matter - 7.32 $12.0 \mathrm{t} \mathrm{ha} \mathrm{h}^{-1}$ and optimal botanical composition of a sward during many years. On unlimed soils ( $\mathrm{pH}_{K C L}<4.0 \mathrm{in}$ 1997) dry matter yields of grass sward was substantially lower and there was observed disappearance of seeded valuable grasses out of the sward and increase of herbs and non-seeded grasses -Festuca rubra L., Agrostis tenuis Sibth., Taraxacum officinale Wigg. and others. Liming of soils increased dry matter yield in treatments with high doses of $N$ (300-400) fertilizer.
\end{abstract}

Keywords: botanical composition, dry matter, fertilizer, liming, perennial grasses, swards.

\section{Introduction}

One of the high-quality, wholesome and cheap feed sources is a perennial grasses. Grasslands are important elements of agricultural production under many management systems. Perennial grasses in Latvian meadows and pastures occupy nearly half of agricultural land. They are the most economical consumers of applied fertilizer. Therefore this is the most important plant group in our country and the main source of energy and nutrients for dairy cattle, meat animals, horses and other domestic animals [1].

Usually, within grassland sward there are several components with the aim to improve the use of nutrients, received from the soil as well as to get a better chemical composition of the green mass, and to obtain longevity. Sustainability is a measure of our ability to produce food with the maximum efficiency combined with the minimum damage to the environment [2]. Due to a big proportion of perennial grasses areas it is important to establish way of grasslands cultivation for more long and effective use of swards with the aim to save resources, environment and biodiversity.

To find out the yield ability and longevity of perennial grasses swards according to the fertilizer, in 1974 was established an appropriate test. Originally it was intended to clarify the role of irrigation too, therefore, chosen a relatively high mineral fertilizer rates, but over time, failed to successfully solve the technical problems related to irrigation, so a trial was added with the liming variants. Part of the research results published in the references in those works $[3,4,5,6,7,8,9]$. The research shows that grassland perennity, its botanical composition and productivity are influenced by the fertilizers and the way how they are used $[6,7,9]$.

In this article is continued to summarize the results of research in recent years.

\section{Materials and methods}

The trial was established in 1974, on the sod-faintly podzolic sandy-loam soil within two grassland swards:

1. cocksfoot (Dactylis glomerata L.) $20 \mathrm{~kg} \mathrm{ha}^{-1}+$ white clover (Trifolium repens L.) $4 \mathrm{~kg} \mathrm{ha}^{-1}$; 
2. grass mixture: meadow fescue (Festuca pratensis Huds) $10 \mathrm{~kg} \mathrm{ha}^{-1}+$ timothy (Phleum pratense L.) $4 \mathrm{~kg} \mathrm{ha}^{-1}+$ perennial ryegrass (Lolium perenne L.) $4 \mathrm{~kg} \mathrm{ha}^{-1}+$ meadow grass (Poa pratensis L.) $3 \mathrm{~kg} \mathrm{ha}^{-1}+$ red clover (Trifolium pratense L.) $4 \mathrm{~kg} \mathrm{ha}^{-1}+$ white clover (Trifolium repens L.) $2 \mathrm{~kg} \mathrm{ha}^{-1}$.

There was choosed cultivars: cocksfoot 'Priekulu 30', meadow fescue 'Priekulu 519', timothy 'Priekulu', perennial ryegrass 'Priekulu 59', meadow grass 'Priekulu 129', red clover 'Stendes velais', white clover 'Priekulu 60'.

The fertilizer doses were the following:

$$
\begin{aligned}
& \mathrm{N}-0,100,200,300,400 \mathrm{~kg} \mathrm{ha}^{-1} ; \\
& \mathrm{P}_{2} \mathrm{O}_{5}-0,50,100,150,200 \mathrm{~kg} \mathrm{ha}^{-1} ; \\
& \mathrm{K}_{2} \mathrm{O}-0,75,150,225,300 \mathrm{~kg} \mathrm{ha}^{-1} .
\end{aligned}
$$

Phosphorus and potassium fertilizers were applied in autumn or in early spring. Nitrogen mineral fertilizer in the form of ammonium nitrate was applied in spring, by resurgence of vegetation, and after the $1^{\text {st }}$ and $2^{\text {nd }}$ harvests as well.

Before establishing the grassland swards, the soil was limed $\left(\mathrm{CaCO}_{3} 3 \mathrm{tha}^{-1}\right)$.

Grassland productivity (the green mass and the dry matter harvest) was defined during the $3^{\text {rd }}$ mowing periods, but from 2005 during the $2^{\text {nd }}$ mowing periods.

Botanical composition of the swards was determined at the beginning of June before $1^{\text {st }}$ cut in $20 \times 25 \mathrm{~cm}$ accounting areas by visual evaluation of cropped area of each species. In depends of species quantity and its distribution regularity there were estimated 10- 30 accounting places in each trial plot. The trial data were statistically processed using analysis of variance.

\section{Results and discussion}

The swards of grasses produced during the trial were of various qualities, depending on the particular fertilizer application that caused disappearance of seeded grasses away and spreading of other species of herbs. The differences among the swards in the variants without liming were determined both by the soil $\mathrm{pH}_{\mathrm{KCl}}$ level and the changes in amount of nutritive substance, but in the variants with liming occurred that the main effect on these differences had changes in plant nutrients.

The proportion of seeded grasses in the composition of sward during the 36-year trial period was gradually reduced and as a result in some places seeded grasses completely disappeared away and were replaced by non-seeded perennial and legume grasses, and broadleaf species plants as well. Considerable effect on the number of species counted up in 2010 had the fertilizer application, especially nitrogenous fertilizer. There was observed an interconnection: higher fertilizer rates produce smaller number of species in a sward. The evaluation of the species showed that the most diversity in species, on average 11, were present in the variants with fertilizer inputs of $100 \mathrm{~kg} \mathrm{~N} \mathrm{ha}^{-1}$, the least, on average 3, were present in the highyielding variants with liming and high inputs of nitrogenous fertilizer.

Changes in a sward were easier to establish in the variants with cocksfoot. Though in the assessment of changes in a poly-component sward there must be taken into account that smooth meadow grass (Poa pratensis), sown with grass mixture, is not distinguishable from its wild subspecies. In order to characterize botanical composition in a sward, Antonijs and Rumpans [9] used the tiller counting method; however, there must be taken into account the fact that tillers of various species are of different shape. In particular, it concerns culm grasses and broad-leaved species; besides, the obtained results do not disclose if there are any areas not covered with plants.

Legume grasses were not present in the sward already after 5-6 years growing, but in some variants without nitrogenous fertilizer applied or with small rates of nitrogenous fertilizer and high rates of phosphorous and potassium fertilizer applied there were present white clover (Trifolium repens L.). White clover persists and spreads well in limed $\left(\mathrm{pH}_{\mathrm{KCl}}\right.$ 5.6-7.0) legume 
grass mixtures [10]. During the experiments, white clover content in the sward ranged from $18 \%$, in 1997 , to very little $8 \%$, in 2010 , for the variant 022 without using of nitrogen fertilizer. It is common that the white clover content in a sward is higher in autumn; white clover was more spread in the variants with little nitrogen and high phosphorus and potassium rates applied, if the weather was wet.

After 22 years, acidity of topsoil $(0-20 \mathrm{~cm})$ in the variants without liming was increased from $\mathrm{pH}_{\mathrm{KC} 1}$ 5.7-6.2 to $\mathrm{pH}_{\mathrm{KC1}}$ 4.4-5.3; after 10 years more, it was $\mathrm{pH}_{\mathrm{KCI}} 3.5$. In the topsoil $(0-10 \mathrm{~cm})$ such a $\mathrm{pH}$ level was recorded already after 22 years of cultivation when interconnection between the composition of sward and the soil $\mathrm{pH}$ level in upper soil was evaluated. Acidification of the soil resulted from calcium remove by yields, as well as due to application of mineral fertilizers. Over the last years of the trial the fertilization with $100 \mathrm{~kg} \mathrm{~N} \mathrm{ha}{ }^{-1}$ produced average soil $\mathrm{pH}_{\mathrm{KCI}} 4,2$, in the variant with $300 \mathrm{~kg} \mathrm{~N}^{-1}$ the average soil $\mathrm{pH}_{\mathrm{KCI}}$ was 3,8 . Further decline in the soil $\mathrm{pH}$ was prevented by liming; liming repeated after 10 years, in 1997, ensured that the soil $\mathrm{pH}$ was even higher than before it. The proportion of seeded perennial grasses in a sward after 22 years had changed significantly. It must be noted that the term "seeded perennial grasses" in this case is a quite relative term, because along with the seeded smooth meadow grass ( $P$. pratensis L.) in the sward there appeared also its wild forms. Similarly in the sward of cocksfoot (Dactylis glomerata L.) there also were present meadow grasses ( $P$. pratensis L., $P$. trivialis L.), meadow fescue ( $F$. pratensis Huds.), and timothy (Phleum pratense L.). Cocksfoot present in a poly-component sward was regarded as seeded culm grass. Each of these perennial grasses is of high productivity and quality and the proportion of them in a sward determines the total value of a sward.

Higher amount of seeded perennial grasses $(65 \%$ - $77 \%)$ after 22 years was present in the swards of the variants with liming, whereas the amount of seeded grasses for the variants without liming varied, depending on fertilization. The highest proportion of seeded perennial grasses, on average $42 \%$, was present in the variants with fertilizer dose $\mathrm{N}_{100}$. Increasing of fertilizer $\mathrm{N}$ input up to $200 \mathrm{~kg} \mathrm{ha}^{-1}$ had a negative effect - only $26 \%$ of seeded grasses were left in the sward; in the variants with $\mathrm{N}$ input $300 \mathrm{~kg} \mathrm{ha}^{-1}$ - on average only $9 \%$ of seeded grasses remained. Because of the high level of potassium and phosphorous fertilizer applied, in the sward of the variant 444 the proportion of seeded grasses was still at comparatively high level - $65 \%$, while in the variants without nitrogenous fertilizer applied the seeded grasses had almost disappeared away (Table 1). A few seeded stem grasses were present also in the variants without phosphorous or potassium fertilizer applied $(202,220)$, and in the variants with small doses of fertilizers applied $(422,311,331)$ what caused shortage of the easy accessible nutrients in soil, i.e. potassium content in the soil was reduced and ranged from 43 to $59 \mathrm{mg} \mathrm{kg}^{-1}$; phosphorus, from 99 to $133 \mathrm{mg} \mathrm{kg}^{-1}$.

The proportion of the seeded stem grasses in the sward continued to decline during a continued usage of the sward for over 10 years, and in 2010 , in the $36^{\text {th }}$ year after the establishment of the trial, even in the best variants the seeded grasses formed only $50 \%$ of the sward. The liming and the relatively high soil $\mathrm{pH}$ could not ensure that seeded grasses remained in the sward, especially in the variant with $\mathrm{N}_{300}$ application. The withering of seeded grasses may be determined by potassium deficiency, because even at the variants with high rates of potassium fertilizer applied $\left(225 \mathrm{~kg} \mathrm{~K}_{2} \mathrm{O} \mathrm{ha}{ }^{-1}\right)$ the concentration of the easy absorbable potassium in soil was poor and ranged from 32 to $117 \mathrm{mg} \mathrm{kg}^{-1}$. In the variants without liming and lower doses of nitrogenous fertilizer applied the soil $\mathrm{pH}_{\mathrm{KCl}}$ level remained at 4.0 or was higher, and the average proportion of the seeded grasses remained $42 \%$ of the sward. Such a negative factors as the rise of soil acidity and the deficiency in potassium may have disadvantageous effect if higher doses of nitrogen are applied.

As the seeded grasses fell out from the swards, other grasses gradually invaded the place. After 22 years, the couch grass (Elytrigia repens L.) began to invade more intensively in the 
variants with medium or high nitrogenous fertilizer doses $\left(\mathrm{N}_{200}-\mathrm{N}_{400}\right)$ applied; it was recorded that couch grass was more spread in the variants without liming. Over the time, the spreading became more intense, and the variants with liming and high nitrogen fertilizer doses $\left(\mathrm{N}_{300}\right)$ applied also were invaded, moreover, after 35 years couch grass had formed several pure swards or the swards with high proportion of couch grass.

Table 1.

The proportion of seeded perennial grasses species and changes of soil $\mathbf{p H}_{\mathrm{KCl}}$ level

\begin{tabular}{|c|c|c|c|c|c|c|c|c|}
\hline \multirow[t]{3}{*}{$\begin{array}{l}\text { Code of } \\
\text { variant }\end{array}$} & \multirow[t]{3}{*}{ Variant } & \multicolumn{2}{|c|}{$\begin{array}{c}\mathrm{pH}_{\mathrm{KCL}} \text { of } \\
\text { soil }\end{array}$} & \multirow{3}{*}{$\begin{array}{c}\text { Listed } \\
\text { number } \\
\text { of } \\
\text { species } \\
2010\end{array}$} & \multicolumn{4}{|c|}{ Seeded perennial grasses in the sward, $\%$} \\
\hline & & \multirow[t]{2}{*}{1997} & \multirow[t]{2}{*}{2006} & & \multirow[t]{2}{*}{1997} & \multicolumn{3}{|c|}{2010} \\
\hline & & & & & & $\begin{array}{l}\text { In } \\
\text { total }\end{array}$ & $\begin{array}{c}\text { Int.al. } \\
\text { Poa pratensis }\end{array}$ & $\begin{array}{c}\text { Dactylis } \\
\text { glomerata }\end{array}$ \\
\hline \multicolumn{9}{|c|}{ Unlimed } \\
\hline 22 & $\mathrm{~N}_{0} \mathrm{P}_{100} \mathrm{~K}_{150}$ & 4.89 & 4.44 & 6 & 35 & 4 & & 2 \\
\hline 202 & $\mathrm{~N}_{200} \mathrm{P}_{0} \mathrm{~K}_{150}$ & 4.69 & 4.10 & 5 & 10 & 8 & 5 & \\
\hline 220 & $\mathrm{~N}_{200} \mathrm{P}_{100} \mathrm{~K}_{0}$ & 4.69 & 3.90 & 5 & 25 & 8 & 8 & \\
\hline 222 & $\mathrm{~N}_{200} \mathrm{P}_{100} \mathrm{~K}_{150}$ & 4.92 & 4.41 & 9 & 65 & 30 & 8 & 40 \\
\hline 224 & $\mathrm{~N}_{200} \mathrm{P}_{100} \mathrm{~K}_{300}$ & 4.83 & 4.48 & 4 & 79 & 54 & 23 & 48 \\
\hline 242 & $\mathrm{~N}_{200} \mathrm{P}_{200} \mathrm{~K}_{150}$ & 4.84 & 4.21 & 7 & 75 & 33 & 7 & 45 \\
\hline 422 & $\mathrm{~N}_{400} \mathrm{P}_{100} \mathrm{~K}_{150}$ & 4.42 & 3.52 & 6 & 3 & 6 & 6 & \\
\hline 444 & $\mathrm{~N}_{400} \mathrm{P}_{200} \mathrm{~K}_{300}$ & 4.27 & 3.92 & 3 & 63 & 35 & 15 & 35 \\
\hline 111 & $\mathrm{~N}_{100} \mathrm{P}_{50} \mathrm{~K}_{75}$ & 4.83 & 3.90 & 6 & 88 & 47 & 25 & 28 \\
\hline 113 & $\mathrm{~N}_{100} \mathrm{P}_{50} \mathrm{~K}_{225}$ & 5.04 & 4.36 & 11 & 59 & 42 & 6 & 27 \\
\hline 131 & $\mathrm{~N}_{100} \mathrm{P}_{150} \mathrm{~K}_{75}$ & 5.30 & 4.64 & 8 & 79 & 43 & 3 & 20 \\
\hline 133 & $\mathrm{~N}_{100} \mathrm{P}_{150} \mathrm{~K}_{225}$ & 4.83 & 3.90 & 10 & 65 & 37 & 1 & 20 \\
\hline 311 & $\mathrm{~N}_{300} \mathrm{P}_{50} \mathrm{~K}_{75}$ & 4.39 & 3.73 & 6 & 28 & & & \\
\hline 313 & $\mathrm{~N}_{300} \mathrm{P}_{50} \mathrm{~K}_{225}$ & 4.88 & 3.85 & 6 & 58 & 5 & 3 & 5 \\
\hline 331 & $\mathrm{~N}_{300} \mathrm{P}_{150} \mathrm{~K}_{75}$ & 4.53 & 3.76 & 3 & 35 & 10 & 10 & \\
\hline 333 & $\mathrm{~N}_{300} \mathrm{P}_{150} \mathrm{~K}_{225}$ & 4.42 & 3.89 & 5 & 52 & 20 & & 30 \\
\hline N1 & Average $\mathrm{N}_{100}$ & 5.00 & 4.20 & 8 & 73 & 42 & 9 & 24 \\
\hline $\mathrm{N} 2$ & Average $\mathrm{N}_{200}$ & 4.79 & 4.22 & 6 & 51 & 26 & 10 & 27 \\
\hline N3 & Average $\mathrm{N}_{300}$ & 4.55 & 3.81 & 5 & 43 & 9 & 3 & 9 \\
\hline \multicolumn{2}{|c|}{ Average $\mathrm{N}_{100,300}$} & 4.78 & 4.00 & 7 & 58 & 25 & 6 & 16 \\
\hline \multicolumn{9}{|c|}{ Limed } \\
\hline $111 \mathrm{k}$ & $\mathrm{N}_{100} \mathrm{P}_{50} \mathrm{~K}_{75}$ & 5.48 & 6.02 & 9 & 73 & 43 & 3 & 27 \\
\hline $113 \mathrm{k}$ & $\mathrm{N}_{100} \mathrm{P}_{50} \mathrm{~K}_{225}$ & 5.43 & 5.93 & 7 & 65 & 45 & 1 & 35 \\
\hline $131 \mathrm{k}$ & $\mathrm{N}_{100} \mathrm{P}_{150} \mathrm{~K}_{75}$ & 5.51 & 5.94 & 7 & 79 & 49 & 18 & 15 \\
\hline $133 \mathrm{k}$ & $\mathrm{N}_{100} \mathrm{P}_{150} \mathrm{~K}_{225}$ & 5.51 & 5.89 & 6 & 77 & 50 & 15 & 25 \\
\hline $311 \mathrm{k}$ & $\mathrm{N}_{300} \mathrm{P}_{50} \mathrm{~K}_{75}$ & 5.45 & 5.09 & 3 & 77 & 11 & 8 & 7 \\
\hline $313 \mathrm{k}$ & $\mathrm{N}_{300} \mathrm{P}_{50} \mathrm{~K}_{225}$ & 5.02 & 5.42 & 3 & 68 & 9 & & 15 \\
\hline $331 \mathrm{k}$ & $\mathrm{N}_{300} \mathrm{P}_{150} \mathrm{~K}_{75}$ & 5.16 & 5.00 & 3 & 70 & 7 & 4 & 5 \\
\hline $333 \mathrm{k}$ & $\mathrm{N}_{300} \mathrm{P}_{150} \mathrm{~K}_{225}$ & 5.11 & 5.43 & 3 & 69 & 8 & & 10 \\
\hline$L S D_{0.05}$ & & 0.66 & 0.61 & & 15 & 17 & & 11 \\
\hline N1 & Average $\mathrm{N}_{100}$ & 5.48 & 5.94 & 7 & 73 & 47 & 9 & 26 \\
\hline N3 & Average $\mathrm{N}_{300}$ & 5.18 & 5.23 & 3 & 71 & 9 & 3 & 9 \\
\hline \multicolumn{2}{|c|}{ Average for limed } & 5.33 & 5.59 & 5 & 72 & 28 & 6 & 17 \\
\hline
\end{tabular}


The proportion of cocksfoot in the swards of sown mixture of cocksfoot with white clover was the highest in the variants with moderate nitrogen rates applied and high phosphorus and potassium rates applied $(222,224,242)$, the proportion of cocksfoot in 2010 ranged from $40 \%$ to $48 \%$.

Smooth meadow grass was present not only in the poly-component mixture variants, but it was present also in the sward of pure cocksfoot; still on the plots where it was sown the proportion of smooth meadow grass was higher by 5-15\%. Along with smooth meadow grass also small amount of rough-stalked meadow grass ( $P$. trivialis), which was not registered, was present on these plots. Rough-stalked meadow grass was more distributed on plots that where fertilized with little or medium doses of nitrogen fertilizer, or sufficiently fertilized with phosphorus and potassium fertilizer.

In the course of time, light spreading of couch grass was observed also in the variants without liming and little doses of nitrogenous fertilizer applied, more significant spreading was observed at the variants with moderate and high doses of nitrogenous fertilizer applied. In the variants with liming compared to ones without liming amount of couch grass was noticeably lower. After 22-year long period of trial, in the variants with $\mathrm{N}_{300}$ applied couch grass formed $23 \%$ of the sward, and in the variants with liming, only $14 \%$. After another 13 years the situation was opposite: in the variants with liming and fertilizer $\mathrm{N}_{300}$ applied the couch grass formed $85 \%$ of the sward, whereas in the variants without liming, $42 \%$ (Table 2).

All the other stem grasses present in the sward were united in the one group. The mostly represented species were red fescue ( $F$. rubra L.) and common bent grass (Agrostis tenius Sibth.), as well as tufted hair grass (Deschampsia caespitose L.) in small amounts. There were registered also a few sedges (Carex L.) and rushes (Juncus L.).

Even though red fescue traditionally is regarded as forage perennial grass of high value or at least of moderate value, according to the regulations on environmental protection it was more convenient to include it in the group with common bent grass. The major difference between these species was that red fescue faster and to greater extent replaced timothy and meadow fescue on the plots where poly-mixture of grasses were sown on.

After 22-year long period, red fescue (F. rubra L.) and bent grass(Agrostis tenius) mainly were present on the plots of the variants without liming; at the greatest extent these species were on the plots (variants 202, 220, 422, 311) with significant deficiency in phosphorus or potassium, or both of them. After 22 years these grasses were light spread, on average $7 \%$ of total amount, in the variants with fertilization rate N100, on average $26 \%-27 \%$, in the variants with higher nitrogenous fertilizer dose applied; 13 years later the proportion of red fescue and bent grass increased also in the variants with fertilizer rate N100, as well as in the variants with liming and the same nitrogenous fertilizer rate applied. At several variants where the first counting recorded high proportion of smooth meadow grass and red fescue, the amount was reduced due to the disappearance, leaving large areas not covered with plants (variants 202, 422).

Broadleaf species were represented mostly by dandelion (Taraxacum officinale Wigg.), less frequently present was meadow buttercup (Rununkulus acris L.) and yarrow (Achillea millefolium L.).

Rare found was also creeping thistle (Cirsium arvense L.), sorrel (Rumex acetosa L.), field chickweet (Cerastium arvense L.), hedge bedstraw (Galium mollugo L.), lady's mantle (Alchemilla vulgaris L.), etc., among them also one lesser butterfly orchid (Platanthera bifolia L.) plant.

Broadleaf weeds, mostly dandelion, were replacing seeded grasses at the variants without nitrogenous fertilizer applied or with small nitrogenous fertilizer rates (N100) applied. The more intense spreading of dandelions in the variants without liming may have occurred due to the application of potassium. 
Table 2.

The DM yields and proportion (\%) of non-seeded grasses in the swards (1997 and 2010)

\begin{tabular}{|c|c|c|c|c|c|c|c|c|c|c|c|c|}
\hline \multirow[t]{2}{*}{$\begin{array}{l}\text { Code } \\
\text { of va- } \\
\text { riant }\end{array}$} & \multirow[t]{2}{*}{ Variant } & \multicolumn{2}{|c|}{$\begin{array}{l}\text { Elytrigia } \\
\text { repens, }\end{array}$} & \multicolumn{2}{|c|}{$\begin{array}{l}\text { Agrostis } \\
\text { tenius, } F . \\
\text { rubra } \text { a.o., }\end{array}$} & \multicolumn{2}{|c|}{$\begin{array}{l}\text { Broad- } \\
\text { leaved } \\
\text { grasses }\end{array}$} & \multicolumn{2}{|c|}{ Clear area } & \multicolumn{3}{|c|}{ DM t ha ${ }^{-1}$} \\
\hline & & $\hat{a}$ & $\stackrel{0}{\circ}$ & $\hat{\sigma}$ & $\stackrel{0}{\circ}$ & $\hat{a}$ & $\stackrel{0}{\stackrel{1}{2}}$ & $\hat{a}$ & $\stackrel{\circ}{\stackrel{0}{\circ}}$ & $\begin{array}{l}+\frac{1}{5} \\
\frac{2}{2}\end{array}$ & ลे & ¿ें \\
\hline \multicolumn{13}{|c|}{ Unlimed } \\
\hline 22 & $\mathrm{~N}_{0} \mathrm{P}_{100} \mathrm{~K}_{150}$ & 3 & 5 & 8 & 39 & 38 & 45 & & & 4.29 & 6.35 & 4.13 \\
\hline 202 & $\mathrm{~N}_{200} \mathrm{P}_{0} \mathrm{~K}_{150}$ & 5 & 8 & 69 & 54 & 6 & 9 & 10 & 23 & 6.82 & 6.41 & 3.26 \\
\hline 220 & $\mathrm{~N}_{200} \mathrm{P}_{100} \mathrm{~K}_{0}$ & 10 & 5 & 50 & 73 & & & 15 & 15 & 6.63 & 4.59 & 3.54 \\
\hline 222 & $\mathrm{~N}_{200} \mathrm{P}_{100} \mathrm{~K}_{150}$ & 20 & 40 & 8 & 20 & 8 & 10 & & & 7.31 & 9.69 & 7.15 \\
\hline 224 & $\mathrm{~N}_{200} \mathrm{P}_{100} \mathrm{~K}_{300}$ & 3 & 43 & 3 & & 16 & & & 4 & 7.86 & 12.0 & 7.32 \\
\hline 242 & $\mathrm{~N}_{200} \mathrm{P}_{200} \mathrm{~K}_{150}$ & 13 & 50 & 5 & 15 & 5 & 3 & 3 & 0 & 7.66 & 10.32 & 6.92 \\
\hline 422 & $\mathrm{~N}_{400} \mathrm{P}_{100} \mathrm{~K}_{150}$ & 15 & 9 & 55 & 39 & & 9 & 28 & 38 & 8.65 & 8.03 & 4.28 \\
\hline 444 & $\mathrm{~N}_{400} \mathrm{P}_{200} \mathrm{~K}_{300}$ & 20 & 55 & 13 & 10 & & & 5 & & & 10.97 & 6.33 \\
\hline 111 & $\mathrm{~N}_{100} \mathrm{P}_{50} \mathrm{~K}_{75}$ & & & 5 & 35 & 8 & 19 & & & 5.53 & 6.75 & 5.36 \\
\hline 113 & $\mathrm{~N}_{100} \mathrm{P}_{50} \mathrm{~K}_{225}$ & 1 & 13 & 10 & 33 & 30 & 14 & & & 5.65 & 8.58 & 5.63 \\
\hline 131 & $\mathrm{~N}_{100} \mathrm{P}_{150} \mathrm{~K}_{75}$ & 1 & 3 & 8 & 23 & 13 & 33 & & & 5.38 & 6.66 & 5.60 \\
\hline 133 & $\mathrm{~N}_{100} \mathrm{P}_{150} \mathrm{~K}_{225}$ & 3 & 15 & 4 & 29 & 29 & 19 & & & 5.88 & 9.06 & 6.47 \\
\hline 311 & $\mathrm{~N}_{300} \mathrm{P}_{50} \mathrm{~K}_{75}$ & 18 & 10 & 40 & 43 & & 8 & 15 & 40 & 7.04 & 6.05 & 3.61 \\
\hline 313 & $\mathrm{~N}_{300} \mathrm{P}_{50} \mathrm{~K}_{225}$ & 20 & 33 & 20 & 34 & & 7 & 3 & 23 & 7.58 & 9.02 & 5.82 \\
\hline 331 & $\mathrm{~N}_{300} \mathrm{P}_{150} \mathrm{~K}_{75}$ & 28 & 60 & 28 & 23 & & 0 & 10 & 8 & 7.46 & 7.92 & 6.17 \\
\hline 333 & $\mathrm{~N}_{300} \mathrm{P}_{150} \mathrm{~K}_{225}$ & 26 & 64 & 15 & 9 & 5 & 8 & 3 & & 8.20 & 11.87 & 6.97 \\
\hline N1 & AverageN $_{100}$ & 1 & 8 & 7 & 30 & 20 & 21 & 0 & 0 & 5.51 & 7.76 & 5.76 \\
\hline $\mathrm{N} 2$ & Average $N_{200}$ & 10 & 29 & 27 & 32 & 7 & 4 & 6 & 8 & 6.74 & 8.60 & 5.64 \\
\hline N3 & Average $\mathrm{N}_{300}$ & 23 & 42 & 26 & 27 & 1 & 5 & 8 & 18 & 7.58 & 8.71 & 5.65 \\
\hline \multicolumn{2}{|c|}{ Average $\mathrm{N}_{100,300}$} & 12 & 25 & 16 & 28 & 10 & 13 & 4 & 9 & 6.55 & 8.24 & 5.71 \\
\hline \multicolumn{13}{|c|}{ Limed } \\
\hline $111 \mathrm{k}$ & $\mathrm{N}_{100} \mathrm{P}_{50} \mathrm{~K}_{75}$ & & 5 & 1 & 15 & 26 & 38 & & & & 7.79 & 5.50 \\
\hline $113 \mathrm{k}$ & $\mathrm{N}_{100} \mathrm{P}_{50} \mathrm{~K}_{225}$ & 3 & 5 & & 8 & 33 & 43 & & & & 10.44 & 6.27 \\
\hline $131 \mathrm{k}$ & $\mathrm{N}_{100} \mathrm{P}_{150} \mathrm{~K}_{75}$ & & & 1 & 27 & 20 & 25 & & & & 7.74 & 5.45 \\
\hline $133 \mathrm{k}$ & $\mathrm{N}_{100} \mathrm{P}_{150} \mathrm{~K}_{225}$ & & 3 & & 5 & 24 & 43 & & & & 9.50 & 6.30 \\
\hline $311 \mathrm{k}$ & $\mathrm{N}_{300} \mathrm{P}_{50} \mathrm{~K}_{75}$ & 9 & 82 & 5 & & 10 & 8 & & & & 8.55 & 6.75 \\
\hline $313 \mathrm{k}$ & $\mathrm{N}_{300} \mathrm{P}_{50} \mathrm{~K}_{225}$ & 8 & 79 & 5 & & 20 & 13 & & & & 12.06 & 7.55 \\
\hline $331 \mathrm{k}$ & $\mathrm{N}_{300} \mathrm{P}_{150} \mathrm{~K}_{75}$ & 23 & 91 & 3 & & 5 & 3 & & & & 8.52 & 6.79 \\
\hline $333 \mathrm{k}$ & $\mathrm{N}_{300} \mathrm{P}_{150} \mathrm{~K}_{225}$ & 18 & 89 & & & 14 & 4 & & & & 13.79 & 8.45 \\
\hline \multicolumn{2}{|c|}{$L S D_{0.05}$} & 11 & 15 & 13 & 15 & 12 & 16 & 13 & 15 & 0.65 & 0.92 & 0.87 \\
\hline N1 & Average $\mathrm{N}_{100}$ & 1 & 3 & 1 & 14 & 26 & 37 & 0 & 0 & & 8.87 & 5.88 \\
\hline N3 & Average $\mathrm{N}_{300}$ & 14 & 85 & 3 & 0 & 12 & 7 & 0 & 0 & & 10.73 & 7.39 \\
\hline \multicolumn{2}{|c|}{ Average for limed } & 7 & 44 & 2 & 7 & 19 & 22 & 0 & 0 & & 9.80 & 6.63 \\
\hline
\end{tabular}

In the time course, the proportion of broadleaf species increased in the variants with small nitrogenous fertilizer rates (N100) applied, and it decreased in the variants with high doses of nitrogenous fertilizer applied, as well as they were invaded by couch grass. The broadleaf species were represented as follows: dandelion $49 \%$; meadow buttercup $15 \%$; sorrel $9 \%$; creeping thistle $7 \%$; yarrow $4 \%$ of total area covered with broadleaf plants. The other broadleaf species were represented only by some few plants or their amount did not exceed a few percents of the total area.

As the seeded grasses disappeared away, in the variants without liming, with topsoil $\mathrm{pH}_{\mathrm{KCl}}$ level below 5, and pronounced deficiency in plant nutrient $(202,220,311,313,331,422)$ 
occurred areas not covered with plants. Such areas with phosphor concentration in the soil at the level $100 \mathrm{mg}$ per $1 \mathrm{~kg}$, and content of potassium in the soil below the level $100 \mathrm{mg}$ per 1 $\mathrm{kg}$ were found already in 1997, after 23 years. The analogous variants with liming were invaded by couch grass and broadleaf plants. In the variants with high nitrogen rates applied, as time went along, areas not covered with plants expanded due to removal of nutrients by high yields leaving the soil in deficiency in nutrients. In summer time, the areas not covered with plants usually wane, as they are invaded mostly by bent grass and shoots of broadleaf plants, but usually these plants do not over-winter and in spring again there are areas not covered with plants.

Also over the time changed the obtained dry matter yields, depending on the particular fertilization. Diversity in dry matter, using multifactor regression method, has been analyzed previously [5], as well as has been explained the long-lasting stability in productivity [6]. The present article reveals an attempt to associate changes in yield to the changes in sward. During the first years after the establishment of trial, the swards were similar to the introduced swards, and productivity was mostly determined by fertilization, not modification it had made to the soil nutrient status, and modifications caused by the sward botanical changes.

At first time the main effect on the differences in yields had the nitrogenous fertilizer applied, however, there was observed also small influence from phosphorous and potassium fertilizer application. As the soil nutrient level and the composition of sward changed due to particular fertilizer application, increased diversity among yields of particular variants, and the standard deviation from the average rate changed from $1.22 \mathrm{tha}^{-1}$ to $2.12 \mathrm{t} \mathrm{ha}^{-1}$, correspondingly, the ratio of variation, from 17.42 to $25.31 \%$; still along with a further degradation of the swards decreased total productivity, as well as the distribution of yields, correspondingly, $1.33 \mathrm{t} \mathrm{ha}^{-1}$, from the standard deviation, and $24 \%$ from the ratio of variation. If initially in the variants without liming the highest yields were produced by the variants with high doses of nitrogenous and potassium fertilizer applied, and sufficient doses of phosphorous fertilizer applied $(422,333)$, then after 22 years only the variant 333 with high doses of phosphorous and potassium fertilizer applied remained productive, but the highest yields were obtained in the variants with medium nitrogenous fertilizer usage (224), and these variants remained high productive also in the further period (Table 2).

Although direct correspondence between changes in a sward and changes in a yield is not significant, still in the variants without liming there is a medium-close correlation between proportion of seeded grasses in sward and dry matter yield, and it is as follows: after 22 years -0.47 , after 13 years -0.65 . A higher productivity had swards with higher proportion of couch grass: if indicated correlation between yields and proportion of couch grass in the sward after 22 years was 0.25 , then after 13 years more it was 0.71 . A very negative correlation, as -0.50 and 0.90 , was established between the yields of dry matter and the proportion of red fescue and bent grass in a sward.

\section{Conclusions}

The applying of balanced fertilizer, which cover runoff of nutrients and prevent the worsening of soil agrochemical qualities provide ensure the longevity and high productivity of perennial grass swards. The highest yields of DM - 7.32 - $12.0 \mathrm{t} \mathrm{ha}^{-1}$ and optimal botanical composition of a swards during many years were provided with medium (224) nitrogenous fertilizer $\mathrm{N}_{200} \mathrm{P}_{100} \mathrm{~K}_{300}$ application.

The task of liming is to prevent of soil acidification under $\mathrm{pH}_{\mathrm{KCl}} 4.0$.

Unbalanced fertilizer of grass mixtures and nutrient deficiency leads to the emergence of areas not covered with plants. 
High nitrogen fertilizer in soils close to neutral increasingly introduced in couch grass (Elytrigia repens L.), which is more productive than the other not-seeded grasses, but does not compensate productivity of sown perennial grasses.

Broad-leaved, mostly dandelion (Taraxacum officinale Wigg.), increasingly introduced in fertilizer use by small, up to $100 \mathrm{~kg} \mathrm{ha}^{-1}$ fertilizer rates of nitrogen as in acid $\left(\mathrm{pH}_{\mathrm{KCl}}\right.$ around 4.0), as in soil close to neutral (around $5.0 \mathrm{pH}_{\mathrm{KCl}}$ ).

\section{References}

1. Jansone, B., Rancane, S., Berzins, P., Stesele, V., Jansons, A. Evaluation of perennial grass mixtures of differnt species and varieties in the central part of Latvia introduced from other European countries. Agronomy Research, Vol.8, Special Issue 3, 2010, p. 563-572.

2. Gutmane, I., Adamovics, A. Productivity aspects of Festulolium and Lolium $x$ boucheanum cultivars. Grassland Science in Europe, Vol. 11, 2006. Proceedings of the $21^{\text {st }}$ General Meeting of the EGF: Sustainable Grassland Productivity. Badajoz, Spain, p. 155-157.

3. Puke, A. Determination of optimal rates of NPK-fertilizer use in many-harvested perennial grass sward. Increased productivity and sustainable use of grasslands and pastures. Riga, Zinatne, 1986, p. 105- 120 (in Russian).

4. Antonijs, A., Berzins, P. What determines the longevity of perennial grasses. Latvian farmer, No. 6, 1998, p. 14 (in Latvian).

5. Antonijs, A., Rumpans, J., Berzins, P. Fertilizer effects on pasture and meadow grasses longevity and productivity. Yield, No.2, 1998, p.5-7 (in Latvian).

6. Berzins, P., Antonijs, A., Rumpans, J. Fertilizer efficiency in the swards of perennial grasses. Agronomy research, No.1, 1999, p.24-29 (in Latvian).

7. Antonijs, A., Adamovics, A., Berzins, P., Rumpans, J. The promotion of productive longevity and quality improvement of perennial grasses swards. The results of long-term field experiments in Baltic states. Proceedings of the International Conference, Jelgava, Latvia, November 22-23, 2000, p.5-10 (in Russian).

8. Antonijs, A., Berzins, P. Phosphorus and potassium balance at the sward of perennial grasses. Agronomy research, No.3, 2001, p.176-179 (in Latvian).

9. Antonijs, A., Rumpans, J. The productivity and botanical composition of perennial grasses swards. Agronomy research, No.4, 2002, p.151-155 (in Latvian).

10. Daugeliene, N. Effect of liming and fertilization on the productivity of a long-term pasture. Grassland Science in Europe, Vol. 11, 2006. Proceedings of the $21^{\text {st }}$ General Meeting of the EGF: Sustainable Grassland Productivity. Badajoz, Spain, p. 122-124.

Anotācija. Daudzgad̄̄gie zālaugi ir nozīmīgākā kultūraugu grupa Latvijā, tie ir galvenais enerǵijas un barības vielu avots slaucamām govīm, galas lopiem, zirgiem un citiem dzīvniekiem. Daudzgadīgie zālaugi Latvijā aiznem gandrīz pusi no lauksaimniecībā izmantojamās zemes platības. Lai noskaidrotu daudzgadīgo

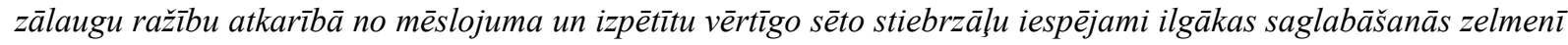
nosacījumus, 1974.gadā ierīkots attiecīgs izmēginājums. Zelmeņu mēslošanai ilgstoši- 36 gadu garumā tika izmantotas nemain̄̄gas minerālmēslojuma NPK devas $\left(0-400 \mathrm{~kg} \mathrm{ha}^{-1}\right)$ daz̄ādās proporcijās. Sākotnēji bija paredzèts noskaidrot arī laistī̌sanas nozīmi, tädēl izvēlētas salīdzinoši lielas minerālmēeslojuma normas, tomēr laika gaitā neizdevās sekmīgi atrisināt ar laistīšanu saistītās tehniskās problēmas, un izmēginājums tika papildināts ar kalı̧̧ošanas variantiem.

36 gadu laikā izmēǵginājuma variantos izveidojušies atš̌kirīgi augsnes apstākli ar dažāădu $P, K$, organiskās vielas saturu un $\mathrm{pH}_{\mathrm{KCl}}$ līmeni, kas būtiski ietekmējis ne tikai zelmeņu raž̄īu, bet arī botānisko sastāru. Daudzu gadu garumā labākos rezultātus- augstāko sausnas ražu un vērtīgo stiebrzālu saglabāšanos zelmenī nodrošinājis minerālmēslojums $N_{200} P_{100} K_{300}$. Nelīdzsvarots mēslojums un kädas uzturvielas iztrūkums noved pie tukšso vietu rašanās zelmenī. Augsta slāpekļa mēslojuma fonā augsnēs tuvās neitrālām pastiprināti ieviešas vārpata. Platlapji, galvenokārt cūkpiene pastiprināti ieviešas, mēslojot ar nelielām, līdz $100 \mathrm{~kg}^{\mathrm{ha}} \mathrm{a}^{-1}$ slāpekla (N) mēslojuma normām $k \bar{a}$ skābās, tā arī augsnēs tuvas neitrālām.

Nekaļ̧otās augsnēs vērojams bütisks zelmeņu sausnas ražas samazinājums un vērtīgo sēto stiebrzālu izkrišana no zelmeņa, kā arī nesēto zālangu un platlapju (F.rubra, Agrostis tenuis, Taraxacum officinale) ìpatsvara pieaugums. 